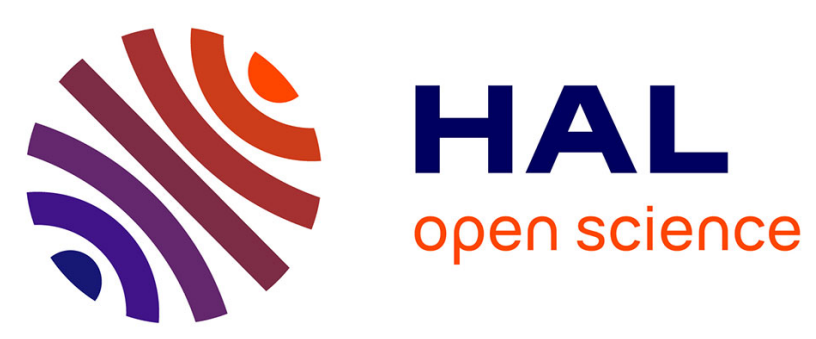

\title{
Influence of oxygen tension on CD133 phenotype in human glioma cell cultures.
}

Nadine Platet, Shi Yong Liu, Michèle El Atifi, Lisa Oliver, François M. Vallette, François R. Berger, Didier Wion

\section{To cite this version:}

Nadine Platet, Shi Yong Liu, Michèle El Atifi, Lisa Oliver, François M. Vallette, et al.. Influence of oxygen tension on CD133 phenotype in human glioma cell cultures.. Cancer Letters, 2007, 258 (2), pp.286-90. 10.1016/j.canlet.2007.09.012 . inserm-00382779

\section{HAL Id: inserm-00382779 https://www.hal.inserm.fr/inserm-00382779}

Submitted on 31 Jul 2009

HAL is a multi-disciplinary open access archive for the deposit and dissemination of scientific research documents, whether they are published or not. The documents may come from teaching and research institutions in France or abroad, or from public or private research centers.
L'archive ouverte pluridisciplinaire HAL, est destinée au dépôt et à la diffusion de documents scientifiques de niveau recherche, publiés ou non, émanant des établissements d'enseignement et de recherche français ou étrangers, des laboratoires publics ou privés. 


\title{
Influence of oxygen tension on CD133 phenotype in
}

\author{
human glioma cell cultures.
}

Nadine Platet ${ }^{\natural}$, Shi Yong Liu ${ }^{\alpha}$, Michèle El Atifi ${ }^{\bullet}$ Lisa Oliver ${ }^{\Theta}$, François M

Vallette $^{\Theta}$, François Berger and Didier Wion*.

INSERM, U836, Université Joseph Fourier, CHU, Grenoble, F-38043,

France ; Equipe Transcriptome, Université Joseph Fourier, CHU, Grenoble ; ${ }^{\theta}$ UMR INSERM, U601, Nantes, F-44035, France.

a Both authors contributed equally to this work.

* corresponding author: Didier.wion@ujf-grenoble.fr.

Abstract: Under standard culture conditions, tumor cells are exposed to $20 \% \mathrm{O} 2$, whereas the mean tumor oxygen levels within the tumor are much lower. We demonstrate, using lowpassaged human tumor cell cultures established from glioma, that a reduction in the oxygen level in these cell cultures dramatically increases the percentage of CD133 expressing cells.

Key words: Cell culture; CD133; glioma; cancer stem cell. 


\section{Introduction.}

In numerous tumors or cancer cell lines, cancer stem cells can be isolated either on the expression of CD133 [1-4] or on the basis of their ability to exclude the fluorescent vital dye Hoechst 33342 [5]. However, recent data have raised some concerns about the use of Hoechst 33342 to identify cancer stem cells from cancer cell lines [6-8]. It has been reported that tumor stem cells derived from glioblastomas cultured in serum-free medium more closely mirror the phenotype and genotype of primary tumors than do serum-cultured cell lines [9]. Indeed the use of serum-containing medium in cell culture has long been controversial and is considered as "non-physiological" since cells are not usually exposed to serum. In addition to serum, it is claimed that oxygen tension in cell culture is another parameter that does not mirror physiological conditions [10-12]. Standard tissue culture incubator conditions are 5\% $\mathrm{CO} 2$ and $95 \%$ air [10-12]. Hence, cells are exposed to oxygen tensions close to $20 \%$ whereas mean tissue oxygen is described to be much lower, ranging from 1 to $5 \%$ in the brain $[10,13]$. Thus, according to these data, current standard culture conditions can be said "normoxic" with regard to our cell culture conventions (cell culture normoxia or "cultural" normoxia) but are indeed hyperoxic with regard to physiological conditions. Although it is clear that cell culture conditions cannot be identical to physiological conditions, deleterious effects of culturing cells at the $\mathrm{O} 2$ concentration of air have been reported. For example, human diploid fibroblast cells grown under 3\% $\mathrm{O} 2$ achieve more population doublings during their life times than when they are cultured at the $\mathrm{O} 2$ concentration of air (20\%) [14]. Likewise, $20 \%$ O2 cell culture conditions alter stem cell function and proliferation $[11,15]$. Consequently it can be assumed that cell culture in a "hypoxic" incubator in 3\% O2 more closely mirrors tissular normoxia. Accumulative evidence points to CD133 as a cell marker suitable for identifying cancer stem cells from brain tumors $[1,16]$. To investigate whether oxygen influences CD133 
expression in glioma cell cultures we compared CD133 expression from tumor dissociated cells cultured as tumor-derived sphere in serum-free medium at $20 \% \mathrm{O} 2$ or $3 \% \mathrm{O} 2$.

\section{Material and methods}

\section{1- Cell cultures.}

Tumor samples from three glioblastoma and two anaplastic oligodendroglioma were obtained within 2 hours of surgical resection from adult gliomas. Tumor tissue was washed twice in HBSS (Gibco), minced, and enzymatically dissociated for 1 hour at $37^{\circ} \mathrm{C}$ in a solution of HBSS containing $0.1 \%$ dispase (Gibco, $1 \mathrm{u} / \mathrm{mg}$ ) and $0.01 \%$ DNAse (Sigma) with intermittent careful mechanical trituration. Dissociation was sometimes improved by additional 10-15 min treatment with trypsin/EDTA (Gibco, $0.05 \% / 0.53 \mathrm{mM}$ ). Alternatively tissue dissociation was performed using NeuroCult ${ }^{\circledR}$ enzymatic dissociation kit from StemCell Technologies. Cells were then collected by centrifugation, resuspended in defined medium consisting of DMEM/F12 (1:1) containing 0.5 N2 and 0.5 B-27 supplements, $10 \mathrm{mM}$ hepes, 1 X glutamax (all from Gibco), heparin $2 \mu \mathrm{g} / \mathrm{ml}$ (StemCell Technologies), $30 \mathrm{ng} / \mathrm{ml} \mathrm{bFGF}$ and $30 \mathrm{ng} / \mathrm{ml}$ EGF (R\&D systems), and plated without coating. Under these cell culture conditions cells grew and were maintained as floating neurospheres. Cultures under 3\% O2 were maintained in a MCO-5M multi-gas incubator (Sanyo).

Glioma cell lines U87 MG (ATCC HTB-14) and U138 MG (ATCC HTB-16) were maintained in serum containing medium (DMEM supplemented with $10 \%$ fetal bovine serum, as adherent monolayers. When these cells were switched into the defined medium previously described for primary neurosphere culture, they grew as floating spheres.

\section{2- Flow cytometry}


For CD133 cell surface immunostaining, $3.10^{5}$ cells were retrieved from single-cell suspension, and labelled according to the manufacturer's instructions with the following antibodies: anti-CD133/1(AC133)-APC, anti-CD133/2(293C3)-PE (Miltenyi Biotec), and their respective controls (IgG1 isotype control-APC and IgG2b isotype control-PE, R\&D systems). Cytometric analysis was performed on a FACSCalibur machine (BD Biosciences). Dead cells were excluded from the plots based on 7-AAD staining (BD via-probe).

\section{3- Real time quantitative RT-PCR.}

Total RNA was extracted using NucleoSpin ${ }^{\circledR}$ RNA $\Pi$ kit (Macherey-Nagel) and $0.5 \mu$ g was reverse transcribed for $60 \mathrm{~min}$ at $42^{\circ} \mathrm{C}$ using M-MLV Reverse Transcriptase (Promega) with random hexamers. Real-time PCR reactions were carried out with SYBR Green PCR master $\operatorname{mix}($ Qiagen) and performed in $22 \mu \mathrm{l}$ reactions using $1 / 25$ of the cDNA produced by reverse transcription. The following conditions were used for PCR: $95{ }^{\circ} \mathrm{C}$ for $10 \mathrm{~min}, 95{ }^{\circ} \mathrm{C}$ for 15 sec, $55{ }^{\circ} \mathrm{C}$ for $25 \mathrm{sec}$, and $72{ }^{\circ} \mathrm{C}$ for $30 \mathrm{sec}$, in 50 cycles. The sequence-specific primers of CD133 and $\beta$-actin were as follows: CD133 : TCCACAGAAATTTACCTACATTGG(sense) and CAGCAGAGAGCAGATGACCA(antisense); $\beta$-actin :CTCCTGAGCGCAAGTACTCC (sense) and TGTTTTCTGCGCAAGTTAGG (antisense). The analysis of RT-PCR output data followed the $\Delta \mathrm{Ct}$ method, using the relationship : $\Delta \mathrm{Ct}=\operatorname{Ln}($ Fold change $) / \mathrm{Ln}(2)$. The $100 \%$ efficiency of PCR was checked for each target gene using the standard curve method. For each sample, the gene expressions were normalized by the relative expression of housekeeping gene $\beta$-actin (ACTB) which showed a stable expression in any conditions.

\section{Results and discussion.}

Five tumor-neurosphere cultures were established from three freshly resected and dissociated human glioblastoma and two anaplastic oligodendroglioma. These cell cultures proliferated as 
tumor-sphere in serum-free medium and were tumorigenic when injected intracerebrally in nude mice (data not shown). To determine whether oxygen tension affects CD133 expression, cell cultures were maintained either at 20\% O2 ("cell culture normoxia") or 3\% O2 ("tissue normoxia"). Under these different conditions clear differences were observed since cell cultures contained a higher percentage of CD133+ cells under $3 \% \mathrm{O} 2$ compared to $20 \% \mathrm{O} 2$ (Fig. 1 C,D and Fig 2 A,C,E,G). Analysis of CD133 expression by quantitative RT-PCR confirmed FACS data (Fig. 1B and Fig 2 B,D,F,H). We next investigated whether these results can be extended to commercial glioma cell lines obtained from ATCC. For this purpose experiments were performed on two widely used glioma cell lines (U87MG, ATCC HTB-14 and U138MG, ATCC: HTB-16) which have been established and maintained in serum-containing medium under $20 \%$ oxygen for many passages. Although these cell lines can be adapted to serum-free culture conditions and grew well as tumor-sphere, they did not express detectable levels of CD133 (data not shown). This suggests that selection of CD133cell populations might have occurred in these cell lines during their propagation under $20 \%$ $\mathrm{O} 2$ in media containing serum. Thus, prolonged in vitro passage of glioma cells in standard cell culture conditions could lead to the outgrowth of CD133- cell clones with profound "de novo" genetic and/or epigenetic changes [9]. Indeed, cells have evolved several mechanisms for counteracting oxidative stress, and it will be interesting to determine whether overexpression of enzymes involved against oxidative damage (superoxide dismutase, glutathione peroxidase, aldo-keto reductase...) occurs in $20 \% \mathrm{O} 2$ compared to $3 \% \mathrm{O} 2$. This observation raises again the question on the behaviour of such cells when they are injected to induce experimental tumors and are therefore challenged by lower oxygen tension. In this regard it is note worthy that U138MG (ATCC: HTB-16) cells are described as non tumorigenic according the ATCC catalogue. 
Our results are obtained by culturing cells under 3\% O2. As discussed in the Introduction, this so-called "hypoxic" condition are considered as more physiological than the $20 \%$ oxygen tension used in traditional tissue culture. Indeed, oxygen tension in the brain is about 3\% $[10,13]$ and should be even lower in tumor tissues [17]. However, we are aware that oxygen levels displayed by incubators do not exactly reflect the oxygen tension at the cell level which depends of several parameters such as the depth of the medium, and cell density [11]. On the other hand, culturing cells as neurospheres could generate a $\mathrm{pO} 2$ gradient from the periphery to the centre of the neurosphere resulting in a lower oxygen tension within the core of neurospheres. Likewise, we cannot exclude some possible biological effects which might occur when cells cultured in $3 \% \mathrm{O}_{2}$ were exposed to atmospheric oxygen tension as a consequence of cell passaging. Hence, our results need to be interpreted being aware of these potential limitations.

In conclusion, our data are consistent with several data reporting the deleterious effects of using traditional tissue culture conditions with $20 \%$ oxygen on the phenotype of normal stem cells $[11,15,16]$. They are also in agreement with the recent report that low oxygen tension increases CD133 expression in medulloblastoma cells [18]. Moreover, they suggest that current "hyperoxic" cell culture conditions under atmospheric oxygen $(20 \%$ O2) could be one of the parameters involved in the decrease/disappearance of CD133 phenotype in long-term brain tumor cell cultures.

Acknowledgements: We thank Drs S. Chabardes, E. Gay and D. Hoffman for providing tumor samples. This work was supported by the Ligue contre le Cancer (Comité de l'Isère). 


\section{References}

[1]. Singh, S. K., Hawkins, C., Clarke, I. D., Squire, J. A., Bayani, J., Hide, T., Henkelman, R. M., Cusimano, M. D., and Dirks, P. B. Identification of human brain tumour initiating cells. Nature 432 (2004) 396-401.

[2]. Miki, J., Furusato, B., Li, H., Gu, Y., Takahashi, H., Egawa, S., Sesterhenn, I. A., McLeod, D. G., Srivastava, S., and Rhim, J. S. Identification of putative stem cell markers, CD133 and CXCR4, in hTERT-immortalized primary nonmalignant and malignant tumor-derived human prostate epithelial cell lines and in prostate cancer specimens. Cancer Res. (2007) 67, 3153-3161.

[3]. Yin, S., Li, J., Hu, C., Chen, X., Yao, M., Yan, M., Jiang, G., Ge, C., Xie, H., Wan, D., Yang, S., Zheng, S., and Gu, J. CD133 positive hepatocellular carcinoma cells possess high capacity for tumorigenicity. Int. J. Cancer (2007) 120, 1444-1450.

[4]. Monzani, E., Facchetti, F., Galmozzi, E., Corsini, E., Benetti, A., Cavazzin, C., Gritti, A., Piccinini, A., Porro, D., Santinami, M., Invernici, G., Parati, E., Alessandri, G., and La Porta, C. A. Melanoma contains CD133 and ABCG2 positive cells with enhanced tumourigenic potential. Eur. J. Cancer (2007) 43, 935-946.

[5]. Hadnagy A, Gaboury L, Beaulieu R, Balicki D. SP analysis may be used to identify cancer stem cell populations. Exp. Cell. Res. 312 (2006) 3701-10.

[6]. Platet N, Mayol JF, Berger F, Herodin F, Wion D. Fluctuation of the SP/non-SP phenotype in the C6 glioma cell line. FEBS Lett. 581 (2007) 1435-40.

[7]. Zheng X, Shen G, Yang X, Liu W. Most C6 cells are cancer stem cells: evidence from clonal and population analyses. Cancer Res. 67 (2007) 3691-7.

[8]. Adamski D, Mayol JF, Platet N, Berger F, Herodin F, Wion D. Effects of Hoechst 33342 on C2C12 and PC12 cell differentiation. FEBS Lett. 581 (2007) 3076-3080. 
[9]. Lee, J., Kotliarova, S., Kotliarov, Y., Li, A., Su, Q., Donin, N. M., Pastorino, S., Purow, B. W., Christopher, N., Zhang, W., Park, J. K., and Fine, H. A. Tumor stem cells derived from glioblastomas cultured in bFGF and EGF more closely mirror the phenotype and genotype of primary tumors than do serum-cultured cell lines. Cancer Cell 9 (2006) 391-403.

[10]. Studer, L., Csete, M., Lee, S. H., Kabbani, N., Walikonis, J., Wold, B., and McKay, R. Enhanced proliferation, survival, and dopaminergic differentiation of CNS precursors in lowered oxygen. J. Neurosci. 20 (2004) 7377-7383, 2000.

[11]. Csete, M. Oxygen in the cultivation of stem cells. Ann N Y Acad Sci. 1049 (2005) 18.

[12]. Sullivan, M., Galea, P., and Latif, S. What is the appropriate oxygen tension for in vitro culture? Mol. Hum. Reprod. 12 (2006) 653.

[13]. Zhu, L. L., Wu, L. Y., Yew, D. T., and Fan, M. Effects of hypoxia on the proliferation and differentiation of NSCs. Mol Neurobiol. 31 (2005) 231-242.

[14]. Chen, Q., Fischer, A., Reagan, J. D., Yan, L. J., and Ames, B. N. Oxidative DNA damage and senescence of human diploid fibroblast cells. Proc Natl Acad Sci U S A, 92 (1995) 4337-4341.

[15]. Ezashi, T., Das, P., and Roberts, R. M. Low O2 tensions and the prevention of differentiation of hES cells. Proc. Natl. Acad. Sci. U S. 102 (2005) 4783-4788.

[16]. Bao, S., Wu, Q., Sathornsumetee, S., Hao, Y., Li, Z., Hjelmeland, A. B., Shi, Q., McLendon, R. E., Bigner, D. D., and Rich, J. N. Stem Cell-like Glioma Cells Promote Tumor Angiogenesis through Vascular Endothelial Growth Factor. Cancer Res. 66 (2006) 7843-7848.

[17]. Hockel, M. and P. Vaupel. "Tumor hypoxia: definitions and current clinical, biologic, and molecular aspects." J. Natl. Cancer Inst. 93 (2001) 266-76. 
[18]. Blazek ER, Foutch JL, Maki G. Daoy medulloblastoma cells that express CD133 are radioresistant relative to CD133- cells, and the $\mathrm{CD} 133+$ sector is enlarged by hypoxia. Int J Radiat Oncol Biol Phys 67 (2007) 1-5.

\section{Legend to figures}

Fig. 1: Cells from human glioblastoma, grow as neurosphere, and have increased CD133 expression under $3 \% \mathrm{O} 2$.

A) Glioblastoma cells growing as nonadherent neurospheres.

B) CD133 real time quantitative RT-PCR. Real-time PCR reactions was carried out with SYBR Green PCR master mix(Qiagen) as described in Materials and Methods. For each sample, gene expression was normalized by the relative expression of the housekeeping gene $\beta$-actin (ACTB) which showed a stable expression in any conditions

C) Flow cytometric analysis for CD133 expression of glioma cells cultured under $20 \% 02$ (green) or 3\% O2 (red). CD133 monoclonal antibody was CD133/1 (AC133); nonspecific negative control antibody is in black.

D) Flow cytometric analysis for CD133 expression of glioma cells cultured under 20\% 02 (green) or 3\% O2 (red). CD133 monoclonal antibody was CD133/2 (293C3); nonspecific negative control antibody is in black.

Fig. 2. 
Cell cultures were established in serum-free medium from two additional glioblastoma $[(\mathrm{A}, \mathrm{B})$ and $(C, D)]$ and two anaplastic oligodendroglioma $[(E, F)$ and $(G, H)]$. Cells were grown as floating "neurospheres" and were tumorigenic when injected into nude mouse.

(A, C, E, G): Flow cytometric analysis of CD133 expression. Cells were cultured under 20\% $\mathrm{O} 2$ (green) or 3\% O2 (red). CD133 monoclonal antibody was CD133/1 (AC133); non-specific negative control antibody is in black. Similar results were obtained using monoclonal antibody 293C3 (data not shown).

(B, D, F, H): CD133 real time quantitative RT-PCR. Real-time PCR reactions were carried out with SYBR Green PCR master mix(Qiagen) as described in Materials and Methods. For each sample, gene expression was normalized by the relative expression of the housekeeping gene $\beta$-actin (ACTB) which showed a stable expression in any conditions.

[A,B]: glioblastoma; [C,D]: glioblastoma; [E,F]: anaplastic oligodendroglioma; [G,H]: anaplastic oligodendroglioma. All experiments were performed at least in triplicate. 
A

B
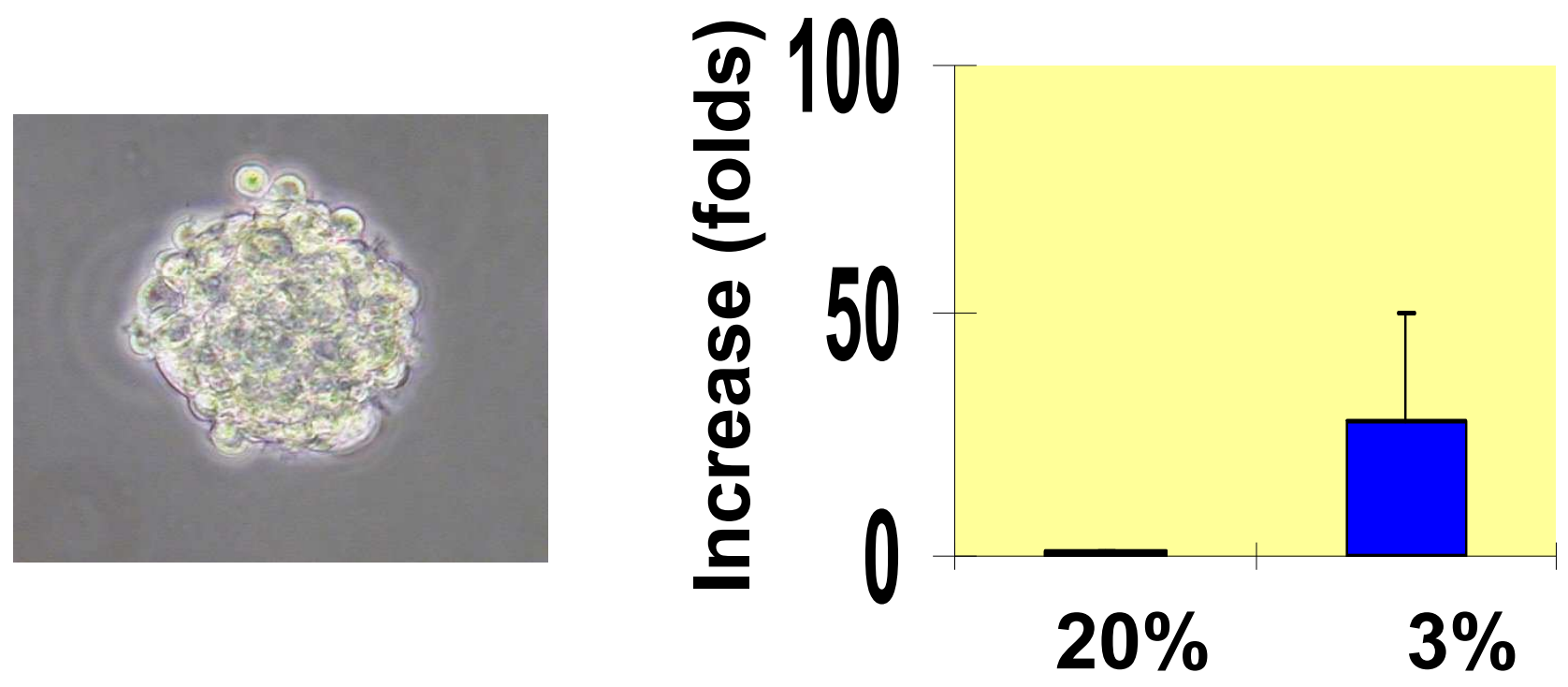

C

D
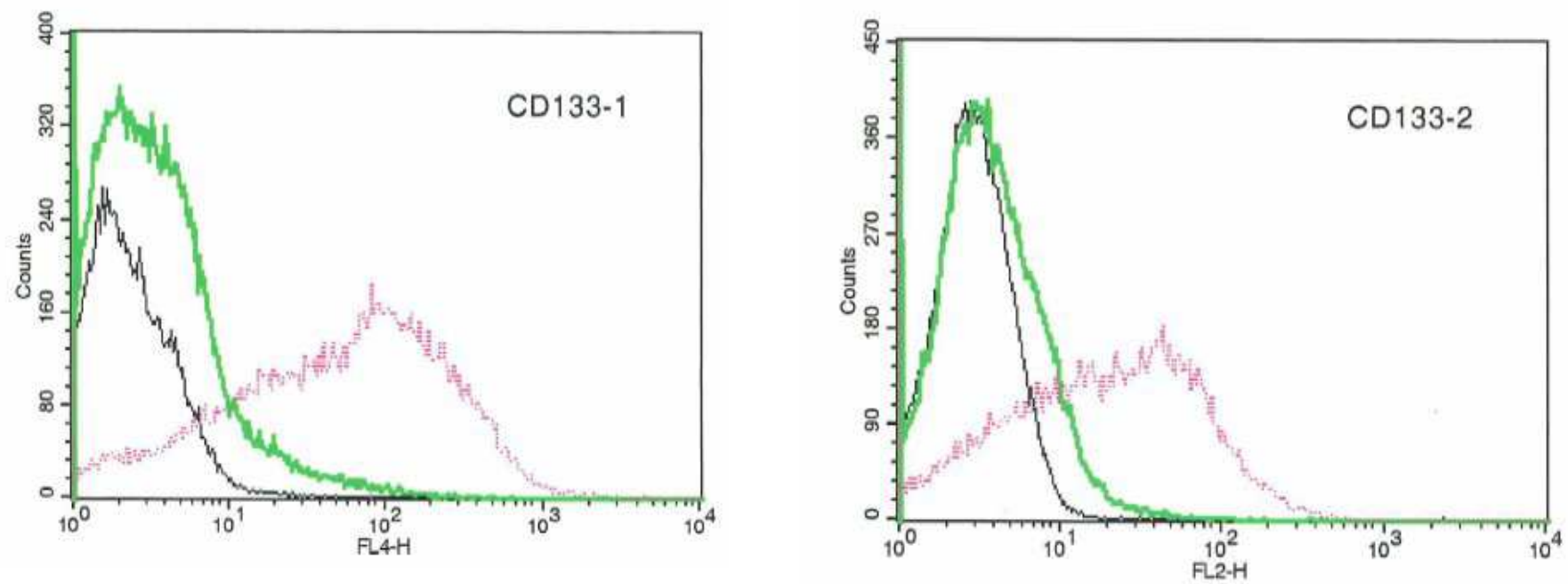

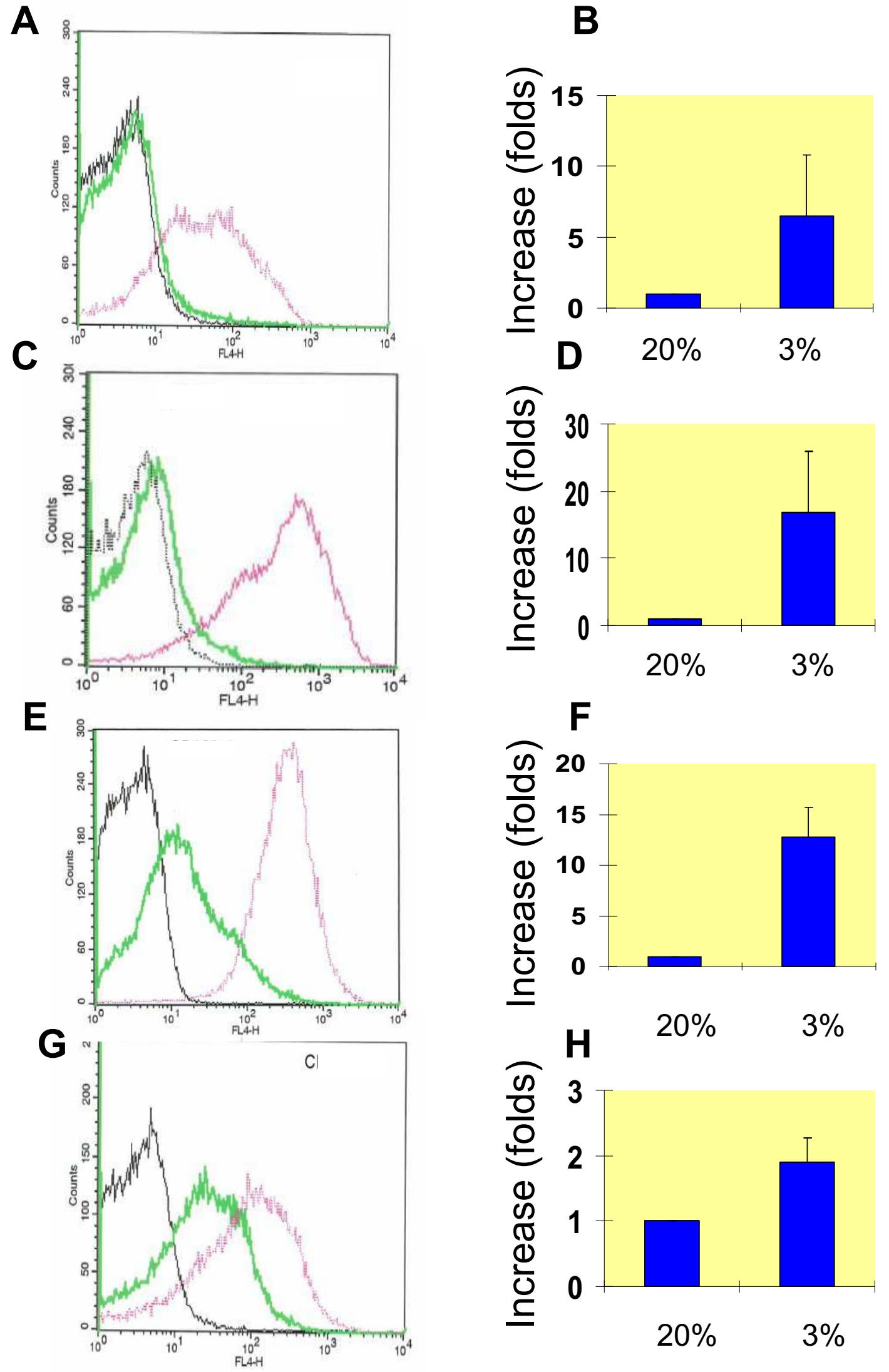